\title{
Phenotypic and Functional Characterization of Human Cytolytic T Cells Lacking Expression of CD5
}

\author{
Barbara E. Bierer, ${ }^{\star *}$ Yasuharu Nishimura, ${ }^{\ddagger}$ Steven J. Burakoff, ${ }^{\text {t5 }}$ and Brian R. Smith* \\ ${ }^{*}$ Division of Hematology, Department of Medicine, Brigham and Women's Hospital, ${ }^{\ddagger}$ Division of Pediatric Oncology, Dana-Farber \\ Cancer Institute, and Departments of *Medicine and ${ }^{\S}$ Pediatrics, Harvard Medical School, Boston, Massachusetts 02115
}

\begin{abstract}
Although the CD5 (T1) antigen was initially described as a pan-T cell membrane glycoprotein, we report that 14 of 40 normal individuals were found to have $5 \%$ or greater of their blood mononuclear cells characterized as $\mathrm{CD}$ (T3) ${ }^{+}$but $\mathrm{CD5}^{-}$ by dual immunofluorescence flow cytometry. These cells expressed normal quantities of surface $\mathrm{CD3}$ and $\mathrm{CD2}$ but low levels of $\mathrm{CD} 7$, were $\mathrm{CD8}^{+}$and $\mathrm{CD4}^{-}$, and $\mathrm{CD16}^{-}$. In order to determine whether cells of this phenotype were functional, six $\mathrm{CD5}^{-}$cytolytic $\mathrm{T}$ lymphocyte (CTL) clones isolated from normal individuals were studied. The CD5 $^{-}$CTL clones all demonstrated normal cytolytic activity against appropriate target cells. Monoclonal antibodies (MAbs) directed against CD3, CD8, CD2, and lymphocyte function-associated antigen 3, but not against CD5, inhibited cytolytic activity. Changes in intracellular calcium $\left(\left[\mathrm{Ca}^{2+} \mathrm{H}\right)\right.$ in response to anti-CDS and antiCD3 MAbs were measured. Stimulation by anti-CD5 MAb alone did not give rise to a change in $\left[\mathrm{Ca}^{2+}\right]_{i}$. However, under conditions of limiting concentrations of anti-CD3 MAb, preincubation of normal $\mathrm{CD5}^{+}$, but not $\mathrm{CD5}^{-}$, clones with anti-CD5 $\mathrm{MAb}$ led to a dramatic enhancement in the ability of anti-CD3 MAb to elicit a rise in $\left[\mathrm{Ca}^{2+}\right]_{i}$. We conclude that $\mathrm{CD5}^{-} \mathrm{T}$ lymphocytes represent a normal lymphoid phenotype. Although CD5 may be involved in $\mathrm{T}$ cell activation when present, these $\mathrm{CD5}^{-} \mathrm{CTL}$ clones appear to express normal cytolytic activity.
\end{abstract}

\section{Introduction}

The CD5 molecule is a lymphocyte cell surface glycoprotein with a relative molecular mass of 67,000 daltons, thought to be expressed on all mature thymocytes, peripheral $\mathrm{T}$ cells, and a subset of B cells (1-7). While the functional role of the molecule is unknown, monoclonal antibodies (MAbs) directed against the CD5 antigen augment $T$-cell proliferative responses to alloantigens and to mitogens, and this proliferation is associated with increased interleukin 2 (IL-2) production and IL-2 receptor expression (8-10). Anti-CD5 MAb has also been shown to enhance $\mathrm{T}$ cell help for B-cell immunoglobulin production (11). These data suggest that the molecule may function to regulate $T$ cell responses.

Address correspondence and reprint requests to Dr. Bierer, Department of Pediatric Oncology, Room 1634, Dana Farber Cancer Institute, 44 Binney Street, Boston, MA 02115.

Received for publication 15 June 1987 and in revised form 25 November 1987.

J. Clin. Invest.

(c) The American Society for Clinical Investigation, Inc.

0021-9738/88/05/1390/08 $\$ 2.00$

Volume 81, May 1988, 1390-1397
CD5 has generally been considered to be a pan-T cell marker coexpressed on all $\mathrm{CD}^{+}$cells. Recently, however, we (12) and others $(13,14)$ have observed that a small population of $T$ cells survive treatment with anti-CD5 MAb plus complement, suggesting the existence of cells that express little or no CD5 antigen. In this report, an analysis of the phenotype and function of the $\mathrm{CD}^{+} \mathrm{CD5}^{-}$population of cytolytic $\mathrm{T}$ lymphocytes (CTL) ${ }^{1}$ was undertaken. $\mathrm{CD}^{+} \mathrm{CD}^{-} \mathrm{CTL}$ clones were generated from healthy donors. Augmentation of antiCD3 MAb induced calcium influx by anti-CD5 MAb observed with $\mathrm{CD}^{+} \mathrm{CD}^{+} \mathrm{T}$ cell clones was not seen with the $\mathrm{CD}^{+} \mathrm{CD}^{-}$cells, confirming the lack of expression by flow cytometric analysis. However, these $\mathrm{CD5}^{-}$clones were able to lyse appropriate target cells, and were generally specific for class I major histocompatibility complex (MHC) antigens. These results indicate that $\mathrm{CD}^{+} \mathrm{CD5}^{-}$cytolytic cells represent a normal lymphoid subpopulation.

\section{Methods}

Cell culture conditions. Cells were grown in culture medium containing RPMI 1640 (M. A. Bioproducts, Bethesda, MD) supplemented with 10\% heat-inactivated fetal bovine serum (FBS) (Hazelton Research Products, Denver, PA), $100 \mathrm{U} / \mathrm{ml}$ penicillin (Gibco, Grand Island, NY), $100 \mu \mathrm{g} / \mathrm{ml}$ streptomycin (Gibco), $10 \mathrm{mM}$ Hepes (M. A. Bioproducts), $2 \mathrm{mM}$ glutamine (Gibco), and $50 \mu \mathrm{M}$ 2-mercaptoethanol (Eastman Organic Chemicals, Rochester, NY). CTL clones were maintained in culture medium to which $10 \%$ IL-2 containing humanconditioned medium had been added. Human-conditioned medium was prepared from 72-h cultured supernatants of pooled phytohemagglutinin (PHA)-stimulated peripheral blood mononuclear cells (PBMC) as described in detail previously (15). The supernatants were concentrated by ammonium sulfate precipitation $(50 \%, 75 \%)$, followed by exhaustive dialysis against phosphate-buffered saline (PBS), filter-sterilized, and stored at $-20^{\circ} \mathrm{C}$.

Purification of cell populations. Venous blood from normal healthy volunteers without prior history of increased infections was collected in preservative-free heparin (Sigma Chemical Co., St. Louis, MO). PBMC were separated on a Ficoll-Hypaque (density 1.077) gradient (Lymphocyte Separation Medium, Bionectics, Kensington, MD) and thoroughly washed. $\mathrm{CD}^{+} \mathrm{CD5}^{-}$cell lines were generated by anti-CD5 $\mathrm{MAb}$ and complement depletion. PBMC, 5-10 $\times 10^{6} \mathrm{cells} \mathrm{ml}^{-1}$, were incubated with $20 \mu \mathrm{g} \mathrm{ml}^{-1}$ anti-Leu $1 \mathrm{MAb}$ (Becton-Dickinson, Mountain View, CA) for $45 \mathrm{~min}$ on ice. Cells were pelleted, washed, and incubated with rabbit complement (Pel-Freez Biologicals, Rogers, AR) at a 1:3 dilution for $1 \mathrm{~h}$ at $37^{\circ} \mathrm{C}$ and then washed. Efficacy of complement lysis was assessed by immunofluorescence analysis (see below).

CTL clones. PBMC, $2 \times 10^{6}$ cells $/ \mathrm{ml}$, were stimulated with irradiated (100 Gy) cells of the human Epstein-Barr virus (EBV)-trans-

1. Abbreviations used in this paper: $\left[\mathrm{Ca}^{2+}\right]_{\mathrm{i}}$, intracellular calcium concentration; CD, cluster of differentiation antigens; CTL, cytolytic $T$ lymphocyte; LFA, lymphocyte function-associated antigen; PE, phycoerythrin. 
formed B-cell line JY (HLA-A2; B7; Dr4, 6; DQ1, 3; DP2, 4), $1 \times 10^{5}$ cells $/ \mathrm{ml}$. The bulk culture was restimulated every 7-10 d with irradiated JY cells. The cultures were maintained in 2-ml wells (Linbro, McLean, VA) in culture medium for the first 3 wk and then supplemented with $10 \%$ human-conditioned medium. Periodically after the third stimulation, cells were cloned by limiting dilution in 96-well round-bottom microtiter plates (Linbro) with irradiated JY cells, 2 $\times 10^{4}$ cells per well, as a feeder layer. Cells were serially diluted to a final calculated concentration of 0.1 cell per well, and later subcloned at 0.1 cell per well to ensure clonality. The $T$ cell clones were maintained in culture medium containing 10\% IL-2-containing humanconditioned medium, and restimulated every $7 \mathrm{~d}$ with irradiated JY cells. The antigen specificity of each clone was established using cytotoxicity of a panel of HLA-typed EBV-transformed B cell lines and by the ability to inhibit such cytotoxicity by appropriate MAb. The phenotype of each clone was established using dual parameter fluorescence-activated cell sorter (FACS) analysis.

Monoclonal antibodies. Four anti-CD5 MAbs were used in this study: anti-Leu 1 (IgG2a), OK-CLL (IgG1) (Ortho Diagnostic Systems, Inc., Raritan, NJ), OKT1 (IgG1) (American Type Culture Collection, Bethesda, MD), and T1 (IgG1) (Coulter, Hialeah, FL) MAb. OKT3 (IgG2a), W6/32 (IgG2a), OKT8 (IgG1), and MMA (IgG2a) MAbs were purchased from the American Type Culture Collection, subcloned, and grown as ascitic fluid of pristane-primed BALB/c mice. MAbs to CDI la (lymphocyte function-associated antigen [LFA]-1), CD2 (TS2/18), LFA-3 (TS2/9), and HLA-DR (LB3.1) have been previously described (16-18). The MAbs 4F2 (19), the generous gift of Dr. J. Strominger, Boston, MA, and MMA (20) were used at a 1:150 dilution of ascitic fluid. Commercial MAbs were also used: anti-Leu 2 (CD8), anti-Leu 3 (CD4), anti-Leu 4 (CD3), anti-Leu 5 (CD2), antiLeu 6 (CD1), anti-Leu 7, anti-Leu 9 (CD7), anti-Leu 11 (CD16), anti-Leu 15 (CD1 lb), anti-HLE1 (CD45), anti-Leu-M3, and antiLeu 12 (CD19) all obtained from Becton-Dickinson. "Control" MAbs (fluorescein [FITC]- and phycoerythrin [PE]-conjugated "irrelevant" murine MAbs) used in the flow cytometric analysis were also obtained from Becton-Dickinson.

Cell surface immunofluorescence and flow cytometry. Cells were washed twice in PBS containing 2\% heat-inactivated FBS and $0.02 \%$ sodium azide (PBS-azide). Approximately $5 \times 10^{5}$ cells were incubated on ice in the dark with saturating concentrations of MAb directly conjugated to FITC or PE. After $\mathbf{3 0}$ min of incubation, the cells were washed three times with PBS-azide, fixed in 1\% paraformaldehyde in PBS, and analyzed on a FACS I analyzer (Becton-Dickinson). Control labeling of cells with FITC- and PE-conjugated "irrelevant" antibodies was performed on all samples to determine positive and negative fluorescence. Markers were set to include $98 \%$ of control-labeled cells in the negative population, and the percent positive cells was calculated as $(\% E-\% C) /(100-\% C)$, where $\% E=$ percentage of cells labeled with the experimental $\mathrm{MAb}$ and $\% C=$ percentage of cells labeled with control reagent. For the analysis of normal PBMC, an additional sample labeled with FITC-conjugated anti-HLE1 and PE-conjugated anti-Leu M3 was used to set appropriate volume/side scatter gates to include all Leu-M3-, $\mathrm{HLE}^{+}$cells and to determine the total number of leukocytes within that gate (defined as percentage $\mathrm{HLE}^{+}$cells) as previously described (21).

Assay for CTL activity. The ${ }^{51} \mathrm{Cr}$ release assay was performed in triplicate in V-bottom microtiter wells (Linbro). Effector cells were counted and added in threefold dilutions. Target cells, preincubated with $0.1 \mathrm{mCi}$ of ${ }^{51} \mathrm{Cr}\left(\mathrm{Na}^{51} \mathrm{CrO}_{4}\right.$, New England Nuclear, Boston, MA) for $2 \mathrm{~h}$, were washed three times, and added at $10^{3}$ cells per well. Microtiter plates were centrifuged at $200 \mathrm{~g}$ for $5 \mathrm{~min}$ and incubated for $4 \mathrm{~h}$ at $37^{\circ} \mathrm{C}$ in $5 \% \mathrm{CO}_{2}$. After incubation, the plates were again centrifuged. $100 \mu$ l of supernatant was harvested, and counted in a gamma counter to determine radioactivity released. The specific lysis is calculated by the formula: $\%$ cytotoxicity $=100[(\mathrm{cpm}$ experimental release - cpm spontaneous release)/(maximum cpm release - cpm spontaneous release)].

When Mab-blocking experiments were performed, MAb was added at the start of the assay. Percent blocking is calculated as percent reduction of specific cytotoxicity, or: \% inhibition $=100$ ( $S R$ control $-(S R+M A b) / S R$ control), where $S R$ is the specific release in the absence of antibody.

Determination of $\left[\mathrm{Ca}^{2+}\right]_{i}$. Human $\mathrm{T}$ cell clones, $2 \times 10^{6} \mathrm{cells} / \mathrm{ml}$, were incubated with $5 \mu \mathrm{M}$ of the acetoxymethyl ester of the fluorophore Indo-1 (Molecular Probes, Junction City, OR) for 45-60 min at $37^{\circ} \mathrm{C}$ on a shaker platform. The Indo-1-loaded cells were washed twice, resuspended in Hanks' balanced salt solution (M. A. Bioproducts) containing $2 \%$ heat-inactivated FBS, and stored in the dark at $37^{\circ} \mathrm{C}$ until analysis. Cytoplasmic calcium was monitored by flow cytometry using a FACS I analyzer as described (22). Briefly, Indo-1 fluorescence was excited by a mercury arc lamp directed through a 353-nm band-pass filter. A 480-nm band-pass filter (Ditric Optics, Inc., Hudson, MA) and a 405-nm line filter (Corion Corp., Holliston, MA) were used to collect fluorescence emission after separation with a 450-nm dichroic filter (Corion Corp.). The ratio of fluorescence emissions, $405 \mathrm{~nm} / 480 \mathrm{~nm}$, reflects the relative intracellular calcium concentration $\left[\mathrm{Ca}^{2+}\right]_{i}(23)$, and is expressed as contour histograms plotted against the volume of the cells analyzed, using a Consort 30 computer (Becton-Dickinson). An increase in the ratio of fluorescence emission greater than 2 SD above baseline mean fluorescence ratio was considered a significant rise in $\left[\mathrm{Ca}^{2+}\right]_{i}$. Temperature was maintained at $37^{\circ} \mathrm{C}$.

\section{Results}

A small population of normal PBL lack surface expression of CD5. The CD5 molecule was initially identified as a "pan-T cell marker," expressed early in thymic ontogeny and on all peripheral T cells $(1,4,5)$. Dual immunofluorescence FACS analysis of peripheral blood mononuclear cells from 40 normal volunteers was performed, and the percentage of lymphocytes of $\mathrm{CD3}^{+} \mathrm{CD5}^{-}$phenotype was found to vary from $0 \%$ to $27 \%$ ( $5 \pm 6 \%$; mean $\pm S D$ ) in these 40 individuals. 14 of the 40 normal donors had greater than or equal to $5 \% \mathrm{CD}^{+} \mathrm{CD}^{-}$ cells. A panel of representative fluorescence histograms is shown in Fig. 1. In the majority of individuals, CD3 and CD5 are coexpressed and $<1 \%$ of cells are $\mathrm{CD}^{+} \mathrm{CD5}^{-}$(Fig. $1 A$ ). However, other individuals ( 14 of 40 ) show a significant population of such cells. One representative individual with $\sim 8 \%$ circulating $\mathrm{CD}^{+} \mathrm{CD5}^{-}$cells is shown in Fig. $1 \mathrm{~B}$. By dual immunofluorescence, the expression of CD5 in the normal PBMC populations varies from negative to brightly positive (Fig. $1, B$ and $D$ ). The $\mathrm{CD}^{+} \mathrm{CDS}^{-}$population appears to occur predominantly in the CD8 (T8, Leu 2$)^{+}$subset (Fig. 1 $D$ ). Thus, as shown in Fig. $1 C$, virtually all $\mathrm{CD}^{+} \mathrm{CD} 4$ (T4, Leu 3$)^{+}$cells are $\mathrm{CD5}^{+}$. The $\mathrm{CD}^{+}$cells are all $\mathrm{CD}^{+}$(Fig. $1 \mathrm{~F}$ ) but only $\sim 50 \%$ are $\mathrm{CD}^{+}($Fig. $1 \mathrm{D})$. The $\mathrm{CD}^{+}$population of cells do not express the cell surface markers CD16 (Leu 11) (Fig. $1 E$ ) nor CD11 (Leu 15, C3bi receptor, data not shown), and, therefore, do not demonstrate the phenotype characteristic of natural killer cells. The $\mathrm{CD}^{+} \mathrm{CD5}^{-}$cells were also found to be uniformly CD2 (T11, Leu 5, the sheep red blood cell receptor) positive, but show weak expression of CD7 (Leu 9) (data not shown). Expression of Leu 7 on these cells was highly variable but generally $<20 \%$ of the $\mathrm{CD}^{+} \mathrm{CD}^{-}$cells expressed this antigen. There was no correlation between frequency of $\mathrm{CD}^{+} \mathrm{CDS}^{-}$cells and the total number of circulating cells expressing the natural killer cell marker CD16, total $\mathrm{CD}^{+}$cells, or the number of circulating $\mathrm{B}$ cells as defined by CD19 (Leu 12).

To determine the phenotypic stability of the $\mathrm{CD}^{+} \mathrm{CD5}^{-}$ population of cells in a given normal individual, seven healthy donors were studied on two to seven occasions over a 2-yr 

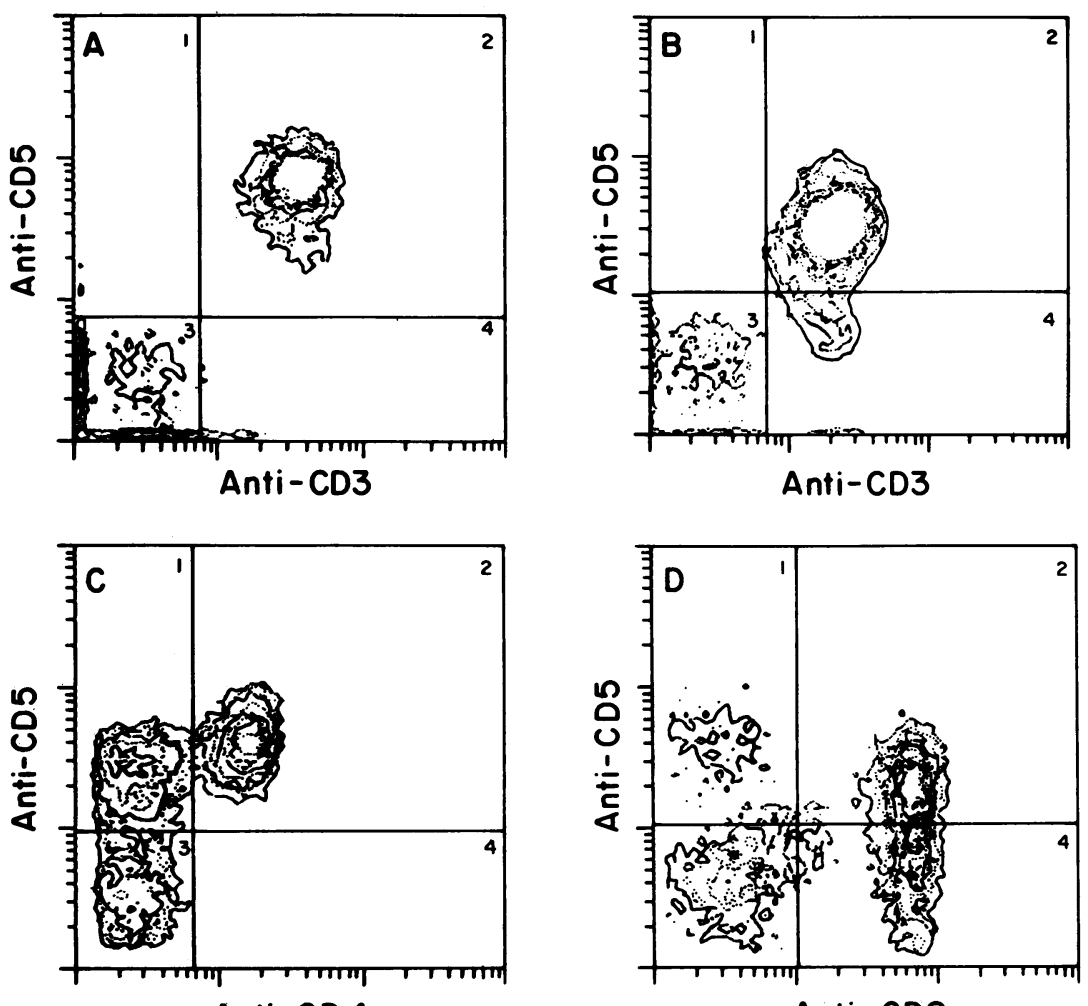

Anti-CD 4

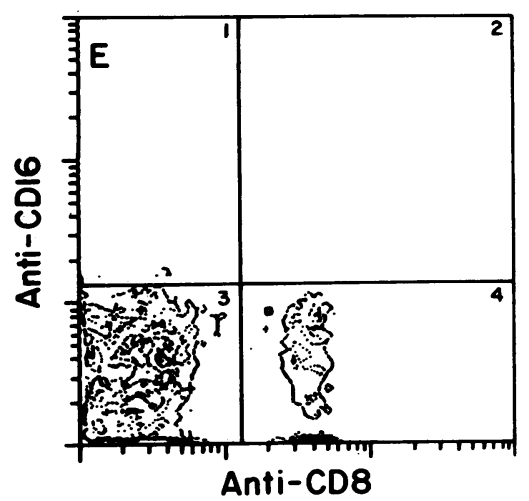

Anti-CD8

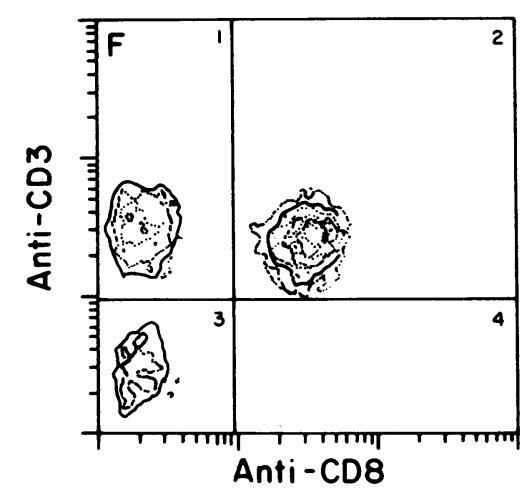

Figure 1. Dual immunofluorescence FACS analysis of PBMC of a normal individual. PBMC were labeled with FITC-conjugated and PE-conjugated MAbs. FITC fluorescence is shown on the abscissa and PE fluorescence on the ordinate; a 3decade logarithmic scale is used. Quadrant markers were set so as to include $98 \%$ of the negative control-labeled cells within quadrant $3 .(A)$ Normal individual with $<1 \% \mathrm{CD}^{+} \mathrm{CD}^{-}$cells labeled with anti-Leu 4 (CD3) and anti-Leu 1 (CD5). (B) Representative CD3 vs. CD5 profile for a patient with $\sim 8 \% \mathrm{CD}^{+} \mathrm{CD5}^{-}$cells. $(C-F)$ Dual-fluorescence profiles from the same individual as in $B$. Labeling conditions and MAb used are described in Methods. period. Serial analysis of all seven individuals demonstrated that the percentage of $\mathrm{CD}^{+} \mathrm{CD}^{-}$cells fluctuated significantly over time, from $<2 \%$ to $7-22 \%$ of peripheral blood lymphocytes. All seven donors had at least one occasion in which the number of $\mathrm{CD}^{+} \mathrm{CD}^{-}$cells was $<2 \%$, and, similarly, at least one occasion in which the number was $>5 \%$.

The percentage of $T$ cells of $C D 3^{+} C D 5^{-}$phenotype is increased by in vitro allostimulation, a phenotype associated with increased lytic capacity. We examined whether the number of $\mathrm{CD}^{+} \mathrm{CD}^{-}$cells could be altered by in vitro allogeneic stimulation. PBMC from three donors were therefore stimulated with the allogeneic human EBV-transformed B cell line, JY, which had been previously irradiated. The phenotype of the cultures was examined. The proportion of $\mathrm{CD}^{+} \mathrm{CD5}^{-}$cells increased from $6 \%$ to $11 \%$, from $7 \%$ to $22 \%$, and from $14 \%$ to $22 \%$ from day 0 to day 6 for the three donors. Stimulation of PBMC with concanavalin A similarly increased the percentage of $\mathrm{CD}^{+} \mathrm{CD5}^{-}$cells to approximately twice baseline levels (not shown).
To determine if the $\mathrm{CD}^{+} \mathrm{CD5}^{-}$cells were capable of lysing the target cell JY, PBMC on day 0 were treated with anti$\mathrm{CD} 5 \mathrm{MAb}$ and complement to lyse contaminating $\mathrm{CD}^{+}$cells. Cytofluorometric analysis revealed that the unlysed PBMC were $49 \% \mathrm{CD}^{+}$and $16 \% \mathrm{CD3}^{+} \mathrm{CD5}^{-}$cells. After depletion with antibody and complement, $<1 \%$ of cells were $\mathrm{CD}^{+}$ $\left(\mathrm{T}^{+}\right)$by indirect immunofluorescence. Both the bulk population and the $\mathrm{CD}^{+} \mathrm{CD5}^{-}$cultures were stimulated with $\mathrm{JY}$, grown in human conditioned medium, and tested for cytolysis (Fig. 2). At equal ratios of effector to target cells, the cytolytic capacity of the $\mathrm{CD}^{+} \mathrm{CD5}^{-}$cells was proportionately greater than the bulk population, reflecting the enrichment for $\mathrm{CD}^{+}$ cells. Proliferation, assessed on day 6 by $\left[{ }^{3} \mathrm{H}\right]$ thymidine incorporation, of the two cultures was identical (not shown). Similarly, if cells were first stimulated with irradiated JY, and prior to assay on day 6, an aliquot was treated with anti-CD5 MAb plus complement, the $\mathrm{CD}^{+} \mathrm{CD5}^{-}$population lysed the target cells at proportionately greater efficiency than the bulk population. Again, proliferation of both populations was equivalent. 


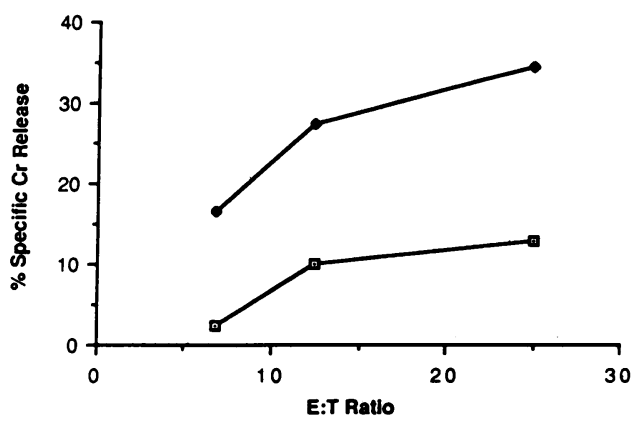

Figure 2. Allospecific lysis by $\mathrm{CD}^{+} \mathrm{CD}^{-}$cells. $\mathrm{PBMC}$ were treated with anti-CD5 MAb plus complement to lyse contaminating $\mathrm{CD}^{+}$ cells, as described in Methods. Untreated cultures or $\mathrm{CD}^{+} \mathrm{CD5}^{-}$ cells were stimulated with the human EBV-transformed cell line JY, cultured in human conditioned medium for $6 \mathrm{~d}$, and then tested for the ability to lyse JY. The percent specific ${ }^{51} \mathrm{Cr}$ release of the target cell by untreated cells $(\square)$ is compared to $\mathrm{CD}^{+} \mathrm{CD}^{-}$cells $(\bullet)$ in a 4-h assay at a number of effector to target $(\mathrm{E}: \mathrm{T})$ ratios.

Functional CTL clones, generated from normal individuals, may be $\mathrm{CD5}^{-}$. To study the function and phenotypic stability of the $\mathrm{CD}^{+} \mathrm{CD5}^{-}$cells which comprise $<5 \%$ of the total $\mathrm{T}$ cell population, we attempted to isolate these cells by cloning. In the bulk population, the $\mathrm{CD}^{+} \mathrm{CD}^{-}$cells expressed the CD8 antigen, a marker which has been associated with cytolytic function (24-27), and we had found the bulk $\mathrm{CD}^{+} \mathrm{CD}^{-}$population capable of cytolysis. Our strategy, therefore, to isolate $\mathrm{CD5}^{-}$clones was to screen for cytolytic activity. Clones were derived by limiting dilution from longterm alloantigen-stimulated bulk cultures from normal individuals and screened for CTL activity. Clones were phenotyped by both dual- and single-parameter immunofluores- cence. In addition to $\mathrm{CD}^{+}$clones, six $\mathrm{CD}^{-}$clones were isolated. The phenotype of a representative $\mathrm{CD5}^{-}$clone is shown in Fig. 3. The $\mathrm{CD}^{-}$clone expressed the T cell surface antigens $\mathrm{CD} 3, \mathrm{CD} 2$, and CD8. It does not express CD4 nor CD7. Furthermore, no binding to CD5 could be detected by indirect immunofluorescence with the anti-CD5 MAb OKT1, T1, Leu 1, or OK-CLL (data not shown). Thus, it is likely that there was no cell surface expression of the CD5 molecule.

Augmentation of anti-CD3 MAb-induced calcium flux by anti-CD5 MAb on $C D 5^{+}$clones vs. lack of augmentation on $C D 5^{-}$populations. By cytofluorometric analysis, the CD5clones did not express the CD5 molecule. We sought to confirm the phenotypic analysis with a functional assessment. Antibody directed against Lyt 1, the murine homologue of CD5 (28), has been shown to augment mitogen-induced increases in $\left[\mathrm{Ca}^{2+}\right]_{i}(29)$. Recently, anti-CD5 MAb has also been shown to increase $\left[\mathrm{Ca}^{2+}\right]_{\mathrm{i}}$ in PBMC (30). We therefore sought to investigate whether anti-CD5 MAb would augment the influx of $\left[\mathrm{Ca}^{2+}\right]_{\mathrm{i}}$ induced by anti-CD3 $\mathrm{MAb}$ on $\mathrm{CD}^{+}$and $\mathrm{CD5}^{-}$ clones. $\mathrm{CD5}^{+} \mathrm{CTL}$ clones were incubated with the calciumsensitive fluorophore, Indo-1 (Fig. $4 \mathrm{~A}$ ). Incubation of these cells with the anti-CD5 MAb anti-Leu 1 or OKT1 did not induce a change in $\left[\mathrm{Ca}^{2+}\right]_{\mathrm{i}}$. Incubation with soluble anti-CD3 MAb, 1:400 dilution of ascites fluid, induced a rapid and sustained rise in $\left[\mathrm{Ca}^{2+}\right]_{i}$. The concentration of anti-CD3 MAb was decreased, to 1:40,000 dilution, until there was no increase in $\left[\mathrm{Ca}^{2+}\right]_{\mathrm{i}}$ observed within the first $10 \mathrm{~min}$ after stimulation (Fig. $4 \mathrm{~B}$ ). However, preincubation of these cells with anti-Leu $1 \mathrm{MAb}$ (Fig. $4 C$ ) markedly enhanced the rise in $\left[\mathrm{Ca}^{2+}\right]_{\mathrm{i}}$ in response to suboptimal doses of anti-CD3 MAb. A MAb recognizing a different epitope on CD5, OKT1, had an identical effect (data not shown). Preincubation of the cells with MAb of the same isotype, such as anti-Leu 9 (CD7), MMA, which
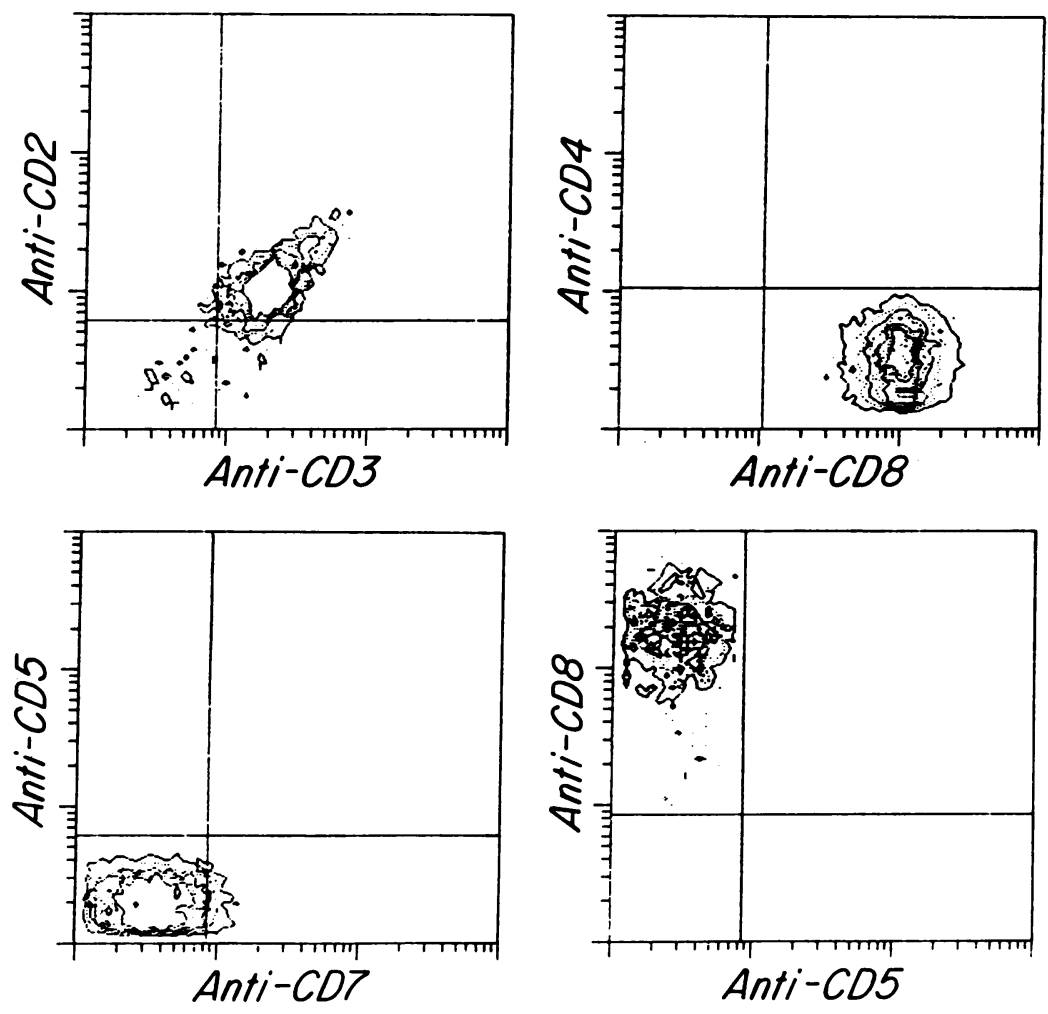

Figure 3. Dual-parameter immunofluorescence of a $\mathrm{CD5}^{-} \mathrm{T}$ cell clone. A CD5 ${ }^{-} \mathrm{T}$ cell clone was stained with FITC-conjugated MAb (horizontal axis) and PE-conjugated MAb (vertical axis) as described in Methods. MAbs used were: anti-CD3 (Leu 4), antiCD2 (Leu 5), anti-CD8 (Leu 2a), anti-CD4 (Leu 3a), anti-CD5 (Leu 1), and anti-CD7 (Leu 9). 

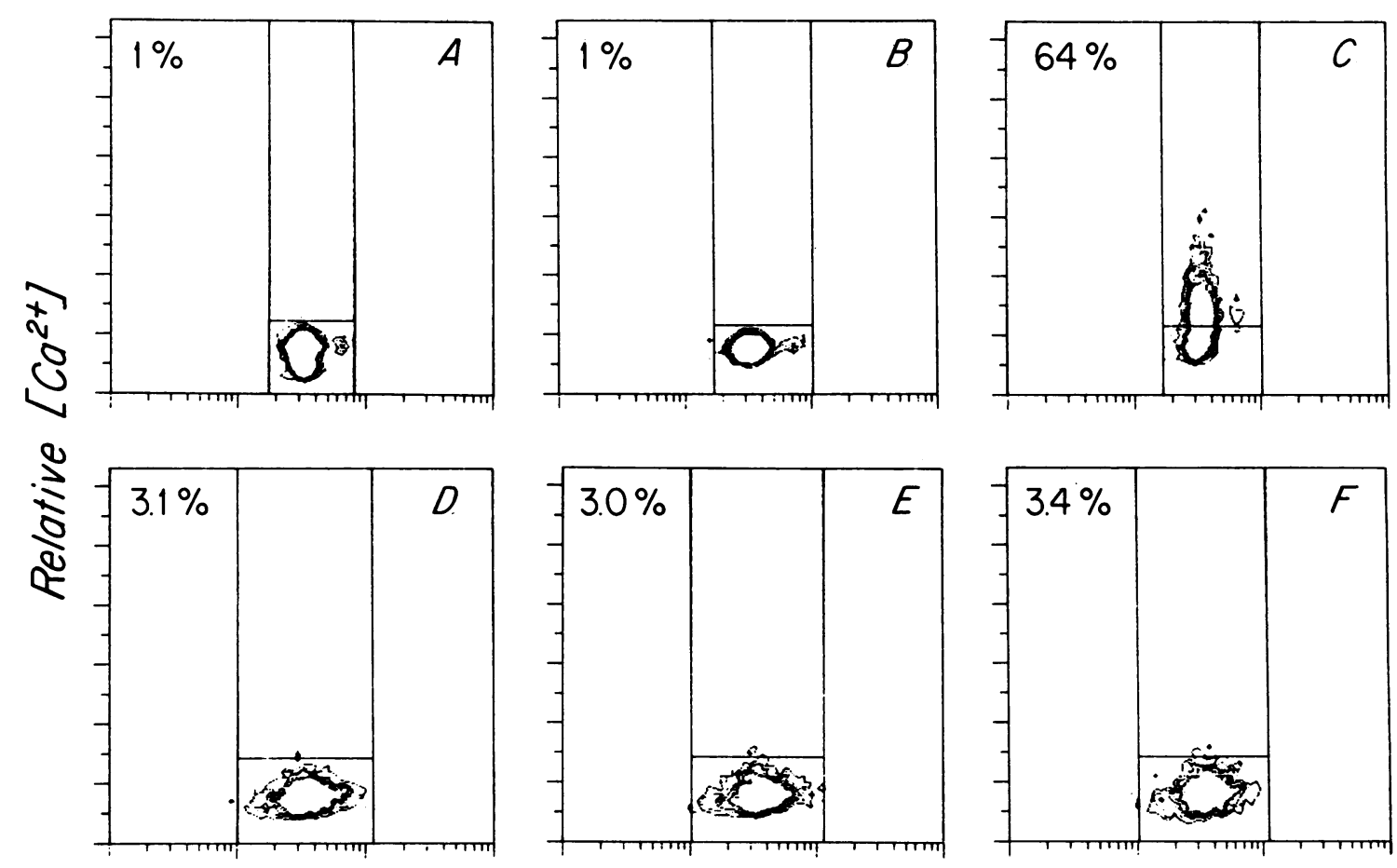

\section{Volume}

Figure 4. Contour histograms of the relative calcium concentration versus volume for a $\mathrm{CDS}^{+} \mathrm{T}$ cell clone $(A-C)$ and $\mathrm{CDS}^{-} \mathrm{T}$ cell clone $(D-F)$. Indo-1-loaded clones were incubated in media alone $(A, D)$ OKT3 MAb, 1:40,000 dilution of ascites fluid $(B, E)$ or anti-Leu 1 MAb, $5 \mu \mathrm{g} / \mathrm{ml}$, for $10 \mathrm{~min}$ followed by OKT3 MAb 1:40,000 dilution $(C, F) .2,500$ events were collected at $4 \mathrm{~min}$ after addition of media or OKT3 MAb. Relative $\left[\mathrm{Ca}^{2+}\right]_{i}$ is determined as the ratio of

recognizes a monocyte-specific antigen (20), or 4F2 did not enhance the anti-CD3 MAb-induced rise in $\left[\mathrm{Ca}^{2+}\right]_{i}$. Similarly, preincubation of cells with anti-Leu $1 \mathrm{MAb}$, followed by stimulation with an isotype control MAb such as W6/32, which recognizes a monomorphic determinant on class I MHC molecules (31), did not induce a rise in $\left[\mathrm{Ca}^{2+}\right]_{i}$. Thus, the augmentation of anti-CD3 MAb-induced $\left[\mathrm{Ca}^{2+}\right]_{i}$ influx is specific to anti-CD5 MAb.

The response to preincubation with anti-CD5 MAb on populations of CTL clones lacking CD5 expression by immunofluorescence was examined. Indo-1-loaded $\mathrm{CD5}^{-} \mathrm{CTL}$ clones were preincubated with anti-CD5 MAb followed by a suboptimal concentration, 1:40,000 dilution of ascites fluid, of anti-CD3 MAb. Under identical conditions of MAb treatment, $\mathrm{CD5}^{-} \mathrm{CTL}$ clones failed to demonstrate an enhancement of anti-CD3 MAb-induced $\left[\mathrm{Ca}^{2+}\right]_{i}$ influx by preincubation with anti-CD5 MAb (Fig. 4, D-F). Thus the lack of expression of $\mathrm{CD} 5$ on $\mathrm{CD5}^{-}$clones by indirect immunofluorescence correlated with the functional loss of the calcium influx observed in response to anti-CD3 MAb.

$\mathrm{CD}^{+} \mathrm{CD5}^{-}$clones exhibit normal cytolytic activity. The $\mathrm{CD}^{-}$clones did not respond to anti-CD5 MAb. We therefore investigated whether these clones exhibited normal CTL activity. Specificity of cytolysis was determined using a panel of HLA-typed target cells and by inhibition of cytolysis by monoclonal antibody blocking. Detailed analysis (Table I) of six $\mathrm{CD}^{+} \mathrm{CD5}^{-} \mathrm{CTL}$ clones showed that five of six of these clones
$405 \mathrm{~nm} / 480 \mathrm{~nm}$ fluorescence emission. A significant rise in the ratio of fluorescence emission is defined as 2 SD above the mean of the baseline $(A, D)$, and is indicated by the horizontal lines. The fraction of cells displaying a significant increase in $\left[\mathrm{Ca}^{2+}\right]_{i}$ is indicated in each panel. Incubation of either clone with anti-Leu $1 \mathrm{MAb}, 5 \mu \mathrm{g} / \mathrm{ml}$, alone did not induce a change in $\left[\mathrm{Ca}^{2+}\right]_{\mathrm{i}}$ (data not shown).

lysed target cells expressing appropriate major histocompatibility complex (MHC) class I antigens and one of six clones lysed target cells expressing appropriate MHC class II antigens. The surface expression of CD3, CD2, and CD8 (Fig. 3) and LFA-1 (not shown) was comparable to $\mathrm{CD5}^{+}$CTL clones. MAb inhibition of cytolytic activity of two MHC class I-specific $\mathrm{CD}^{-}$clones is shown in Table II. The lack of expression of the CD5 antigen did not appear to affect their lytic activity. Moreover, incubation of the clones with anti-CD3, anti-CD2, anti-LFA-3, and anti-CD8 MAb inhibited cytotoxicity, as has been observed for $\mathrm{CDS}^{+}$cytolytic clones $(17,26,27,32,33)$.

\section{Discussion}

In this report, we have analyzed a population of peripheral $\mathrm{T}$ cells which express CD3 but fail to express CD5. By dual-immunofluorescence FACS analysis, this population represents $0-27 \%$ of total circulating $\mathrm{CD}^{+}$lymphocytes in normal individuals. Furthermore, serial analysis of seven individuals demonstrate that this percentage may fluctuate significantly over time, from $<2 \%$ to $7-22 \%$ of peripheral blood lymphocytes. Further phenotypic characterization demonstrated that the cells were a subpopulation of $T$ cells, and not natural killer cells, in that they expressed the $\mathrm{T}$ cell antigens CD3 and CD2, and failed to express CD16. In peripheral blood, $\mathrm{CD}^{+} \mathrm{CD5}^{-}$ cells are predominantly found to express CD8 and not CD4. Alloantigen stimulation leads to an increased number of these 
Table I. Cytolysis by $\mathrm{CD}^{+} \mathrm{CD5}^{-} \mathrm{CTL}$ Clones

\begin{tabular}{|c|c|c|c|}
\hline \multirow[b]{2}{*}{ Clone } & \multicolumn{3}{|c|}{ Effector/target cell ratio } \\
\hline & 18:1 & $6: 1$ & $2: 1$ \\
\hline & \multicolumn{3}{|c|}{ \% specific ${ }^{51} \mathrm{Cr}$ release } \\
\hline \multicolumn{4}{|c|}{ MHC class I-specific } \\
\hline B409 & 92 & 71 & 37 \\
\hline B444 & 75 & 60 & 34 \\
\hline $\mathrm{C} 48$ & 68 & 71 & 27 \\
\hline 315 & 70 & 27 & 4 \\
\hline \multirow[t]{3}{*}{ K41 } & 68 & 24 & ND \\
\hline & \multicolumn{3}{|c|}{ Effector/target cell ratio } \\
\hline & $12: 1$ & $4: 1$ & $1.3: 1$ \\
\hline \multicolumn{4}{|c|}{ MHC class II-specific } \\
\hline K49 & 51 & 31 & 13 \\
\hline
\end{tabular}

* Percent specific ${ }^{51} \mathrm{Cr}$ release of the EBV-transformed B cell line, JY, as described in Methods. The standard deviation of triplicate wells did not exceed $5 \%$ of the specific lysis.

ND, not done.

cells in vitro. Moreover, in alloantigen-stimulated bulk populations, $\mathrm{CD}^{+} \mathrm{CD5}^{-}$cells lysed appropriate target cells with proportionately greater efficiency than the $\mathrm{CD}^{+} \mathrm{CD}^{+}$populations, reflecting the enrichment for $\mathrm{CD}^{+}$cells. In studies using anti-Lyt $1 \mathrm{MAb}, \mathrm{a} \mathrm{MAb}$ to the murine homologue of CD5 (28), analysis of bulk populations of murine lymphocytes has similarly demonstrated that the level of expression of Lyt 1 is higher on helper $T$ cells than on cytotoxic or suppressor subpopulations (34-37).

We undertook a phenotypic and functional evaluation of $\mathrm{CD}^{-}$cytolytic $\mathrm{T}$ cell clones generated by limiting dilution.

Table II. Effect of MAb on CTL-mediated Cytolysis of Target Cells

\begin{tabular}{|c|c|c|c|}
\hline \multirow[b]{2}{*}{ MAb added } & \multirow[b]{2}{*}{ Antigen recognized } & \multicolumn{2}{|c|}{ CTL clones } \\
\hline & & B409 & $\mathrm{C} 48$ \\
\hline & & \multicolumn{2}{|c|}{ \%o specific ${ }^{51} \mathrm{Cr}$ release } \\
\hline None & None & 72 & 71 \\
\hline W6/32 & HLA-A, B, C & $30(58)$ & $31(56)$ \\
\hline LB3.1 & HLA-DR & $68(5)$ & $68(4)$ \\
\hline OKT3 & CD3 & $23(68)$ & $33(54)$ \\
\hline OKT8 & CD8 & $16(78)$ & $44(38)$ \\
\hline Leu 3a & CD4 & $69(4)$ & $72(0)$ \\
\hline TS $2 / 18$ & $\mathrm{CD} 2$ & $16(78)$ & $45(37)$ \\
\hline TS $2 / 9$ & LFA-3 & $44(39)$ & $56(21)$ \\
\hline Leu 1 & CD5 & ND & $70(1)$ \\
\hline
\end{tabular}

CTL-mediated lysis of JY target cells was tested in a standard 4-h ${ }^{51} \mathrm{Cr}$-release assay at $37^{\circ} \mathrm{C}$ (see Methods). The effector/target cell ratio was 6:1. Clones $\mathrm{B} 409$ and $\mathrm{C} 48$ are $\mathrm{CD}^{-} \mathrm{CD}^{+}$and HLA-A2 specific. MAbs were added at the start of the assay, and used at 1:150 final concentration of ascitic fluid. Leu 3a (Becton-Dickinson) was used at 1:60 final concentration of purified MAb. Percent inhibition of cytolysis as described in Methods is shown in parentheses. ND, not done.
Individual clones lacked the surface expression of CD5 as demonstrated by FITC-conjugated or PE-conjugated anti-Leu $1 \mathrm{MAb}$, as well as indirect immunofluorescence using a panel of anti-CD5 MAb. It is therefore unlikely that these cells in fact express low levels of the antigen, although the sensitivity of the analysis may allow as many as 3,000 cell surface molecules to go undetected (38).

We determined whether the small population of $\mathrm{CD}^{+}$ $\mathrm{CD}^{-}$cells were functionally competent. Primary alloreactive $\mathrm{CD}^{+} \mathrm{CD5}^{-}$demonstrated cytolytic activity. $\mathrm{CD}^{-} \mathrm{T}$ cell clones isolated here, selected for lytic ability, were able to kill target cells efficiently. Cytolysis could be inhibited by monoclonal antibodies directed against the recognized $\mathrm{MHC}$ alloantigen, and by MAbs to CD3, CD8, CD2, and LFA-3, suggesting that triggering of lysis through the CD3 molecule and the utilization of accessory molecules was normal for $\mathrm{CD5}^{-}$ clones.

The precise biological role of CD5 remains to be elucidated. The molecular mechanism by which anti-CD5 MAb binding to its ligand augments proliferative responses (6-10, 37) is unknown. Anti-CD5 MAb have been shown to provide the necessary second signal for activation of purified $T$ cells stimulated with solid-phase bound anti-CD3 MAb (9). AntiCD5 MAb was shown here to enhance the anti-CD3 MAb-induced rise in intracellular concentration of calcium, an early signal in $\mathrm{T}$ cell activation in the $\mathrm{T}$ cell clones generated, as has been observed for PBMC (30). The increase in sensitivity of the $T$ cell population to limiting concentrations of anti-CD3 MAb may reflect a direct effect of anti-CD5 MAb on the calcium channel, or upon a distinct intracellular second messenger which, in turn, modulates the change in intracellular calcium stimulated by anti-CD3 MAb. Some $(10,30)$ but not all $(39,40)$ investigators have found a rise in $\left[\mathrm{Ca}^{2+}\right]_{\mathrm{i}}$ induced by the anti-CD5 MAb 10.2 alone, a change which can be amplified by cross-linking the antigen $(30,41)$. Whether this difference reflects a difference in the biologic effect of binding distinct epitopes of the molecule, or in the state of activation of the $T$ cell population studied remains to be determined. We observed no change in $\left[\mathrm{Ca}^{2+}\right]_{i}$ induced by incubation of $\mathrm{CD}^{+}$ CTL clones with the anti-CD5 MAb OKT1 or anti-Leu 1 alone. The increase in $\left[\mathrm{Ca}^{2+}\right]_{i}$ generated by anti-CD5 MAb with limiting concentrations of anti-CD3 MAb in $\mathrm{T}$ cell clones was not observed in $\mathrm{CD}^{-} \mathrm{CD}^{+}$clones. Whether $\mathrm{CD}^{-}$ CTL clones differ from $\mathrm{CD}^{+}$clones in their requirements or threshold for activation, and do not require a signal delivered through the CD5 molecule, or utilize a different compensatory mechanism is presently being investigated.

It has been reported that a population of $\mathrm{CD5}^{-} \mathrm{CD}^{+}$ $\mathrm{CD}^{+} \mathrm{T}$ lymphocytes may be found, not only in normal individuals, but in two clinical conditions. A large proportion of this subset of lymphocytes has been found in recipients of allogeneic bone marrow transplants (42). It is not clear whether these cells represent an early precursor of $\mathrm{CD}^{+} \mathrm{CD}^{+}$ cells or an expansion of a distinct subpopulation of repopulating cells. Recent data have demonstrated that the phenotype of cells from patients with lymphocytosis with neutropenia and other chronic $\mathrm{T}$-cell lymphoproliferative disorders include $\mathrm{CD}^{+}$cells that lack the surface expression of $\mathrm{CD} 5(43,44)$. The functional analysis and growth requirements of these cells has not yet been reported.

Antibodies directed against the CD5 molecule have been used therapeutically in a variety of settings. In vivo administra- 
tion of anti-CD5 MAb has been used to treat lymphoproliferative disorders $(45,46)$. In bone marrow transplantation, antiCD5 MAbs have been used singly $(47,48)$ or as part of a combination of MAbs (49-51) to treat donor marrow ex vivo in an attempt to eliminate contaminating $T$ cells which may contribute to graft versus host disease. The number of residual clonable $T$ cells which survive $T$ cell depletion of bone marrow correlates with the subsequent development of graft versus host disease (52). $\mathrm{CD}^{+} \mathrm{T}$ cells which lack surface expression of CD5 would survive treatment with anti-CD5 MAb plus complement. Surviving $\mathrm{CD}^{+} \mathrm{CD}^{-} \mathrm{T}$ cells, which, as demonstrated here, are capable of clonal expansion and mediating cytolysis, may help to explain the limitations of this approach.

\section{Acknowledgments}

This work was supported by National Institutes of Health grants CA-18662, CA-39542, CA-34129, and AI-23346, a grant from the Dyson Foundation, and American Heart Association, Massachusetts Division, grant 13-506-856. Brian R. Smith is a Leukemia Society of America Special Fellow.

\section{References}

1. Reinherz, E. L., P. C. Kung, G. Goldstein, and S. F. Schlossman. 1979. A monoclonal antibody with selective reactivity with functionally mature human thymocytes and all peripheral human T cell. $J$. Immunol. 123:1312-1317.

2. Wang., C. Y., R. A. Good, P. Ammirati, G. Dymbort, and R. L. Evans. 1980. Identification of a p69, 71 complex expressed on human T cells sharing determinants with B-type chronic lymphatic leukemia cells. J. Exp. Med. 151:1539-1544.

3. Martin, P. J., J. A. Hansen, R. C. Nowinski, and M. A. Brown. 1981. A new human T-cell differentiation antigen: unexpected expression on chronic lymphocytic leukemia cells. Immunogenetics. 11:429-439.

4. Royston, I., J. A. Majda, S. M. Baird, B. L. Meserve, and J. C. Griffiths. 1980. Human T cell antigens defined by monoclonal antibodies: the 65,000 dalton antigen of $T$ cells (T65) is also found on the chronic lymphocytic leukemia cells bearing surface immunoglobulin. J. Immunol. 125:725-731.

5. Engleman, E. G., R. Warnke, R. I. Fox, and R. Levy. 1981. Studies of a human $\mathrm{T}$ lymphocyte antigen recognized by a monoclonal antibody. Proc. Natl. Acad. Sci. USA. 78:1791-1795.

6. Boumsell, L., H. Coppin, D. Pham, B. Raynal, J. Lamerle, J. Dausett, and A. Bernard. 1980. An antigen shared by a human T cell subset and B cell chronic lymphocytic leukemic cells. J. Exp. Med. 152:229-234.

7. van Agthoven, A., C. Terhorst, E. Reinherz, and S. Schlossman. 1981. Characterization of $T$ cell surface glycoproteins $T 1$ and $T 3$ present on all human peripheral $\mathrm{T}$ lymphocytes and functionally mature thymocytes. Eur. J. Immunol. 11:18-21.

8. Ledbetter, J. A., P. J. Martin, C. E. Spooner, D. Wofsy, T. T. Tsu, P. G. Beatty, and P. Gladstone. 1985. Antibodies to Tp67 and Tp44 augment and sustain proliferative responses of activated $\mathrm{T}$ cells. J. Immunol. 135:2331-2336.

9. Ceuppens, J. L., and M. L. Baroja. 1986. Monoclonal antibodies to the CD5 antigen can provide the necessary second signal for activation of isolated resting $\mathrm{T}$ cells by solid-phase-bound OKT3. J. Immunol. 137:1816-1821.

10. Ledbetter, J. A., C. H. June, P. J. Martin, C. E. Spooner, J. A. Hansen, and K. E. Meier. 1986. Valency of CD3 binding and internalization of the CD3 cell-surface complex control $\mathrm{T}$ cell responses to second signals: distinction between effects on protein kinase $\mathrm{C}$, cytoplasmic free calcium, and proliferation. J. Immunol. 136:3945-3852.

11. Thomas, Y., E. Glickman, J. DeMartino, J. Wang, G. Goldstein, and L. Chess. 1984. Biologic functions of the OKT1 cell surface antigen. I. The T1 molecule is involved in helper function. J. Immunol. 133:724-728.

12. Rozans, M. K., B. R. Smith, S. Emerson, M. Crimmins, G. Laurent, T. Reichert, S. J. Burakoff, and R. A. Miller. 1986. Functional assessment of $\mathrm{T}$ cell depletion from bone marrow prior to therapeutic transplant using limiting dilution culture methods. Transplantation. 42:380-387.

13. Berenson, R. J., L. J. Levitt, R. Levy, and R. A. Miller. 1984. Cellular immunoabsorption using monoclonal antibodies. Selective removal of $\mathrm{T}$ cells from peripheral blood and bone marrow. Transplantation. 38:136-143.

14. Jansen, J., E. Srour, C. Cook, D. Walker, and T. Reichert. 1986. $T$ cell depletion with anti-Leu 1 for allogeneic bone marrow grafting. Blood. 68(Suppl. 1):289.

15. Krensky, A. M., S. J. Mentzer, J. L. Greenstein, M. Crimmins, C. Clayberger, T. A. Springer, and S. J. Burakoff. 1985. Human cytolytic $\mathrm{T}$ lymphocyte clones and their function-associated cell surface molecules. In Hybridoma Technology in the Biosciences and Medicine. T. A. Springer, editor. Plenum Press, New York. 559-573.

16. Sanchez-Madrid, F., A. M. Krensky, C. F. Ware, E. Robbins, J. L. Strominger, S. J. Burakoff, and T. A. Springer. 1982. Three distinct antigens associated with human T-lymphocyte-mediated cytolysis: LFA-1, LFA-2, and LFA-3. Proc. Natl. Acad. Sci. USA. 79:7489-7493.

17. Krensky, A. M., F. Sanchez-Madrid, E. Robbins, J. A. Nagy, T. A. Springer, and S. J. Burakoff. 1983. The functional significance, distribution, and structure of LFA-1, LFA-2, and LFA-3: cell surface antigens associated with CTL-target interactions. J. Immunol. 131:611-616.

18. Gorga, J. C., P. J. Knudsen, J. A. Foran, J. L. Strominger, and S. J. Burakoff. 1986. Immunochemically purified DR antigens in liposomes stimulate xenogeneic cytolytic $T$ cells in secondary in vitro cultures. Cell. Immunol. 103:160-173.

19. Haynes, B. F., M. E. Helmer, D. L. Mann, G. S. Eisenbarth, J. Shelhamer, H. S. Mostowski, C. A. Thomas, J. L. Strominger, and A. S. Fauci. 1981. Characterization of a monoclonal antibody (4F2) that binds to human monocytes and to a subset of activated lymphocytes. J. Immunol. 126:1409-1414.

20. Hanjan, S. N. S., J. F. Kearney, and M. D. Cooper. 1982. A monoclonal antibody (MMA) that identifies a differentiation antigen on human myelomonocytic cells. Clin. Immunol. Immunopathol. 23:172.

21. Ault, K. H., J. H. Antin, D. Ginsburg, S. H. Orkin, J. M. Rappeport, M. L. Keohan, P. Martin, and B. R. Smith. 1985. Phenotype of recovering lymphoid cell populations following marrow transplantation. J. Exp. Med. 16:1483-1502.

22. Mentzer, S. J., B. R. Smith, J. A. Barbosa, M. A. V. Crimmins, S. H. Herrmann, and S. J. Burakoff. 1987. CTL Adhesion and antigen recognition are discrete steps in the human CTL-target cell interaction. J. Immunol. 138:1325-1330.

23. Grynkiewicz, G., M. Poenie, and R. Y. Tsien. 1985. A new generation of $\mathrm{Ca}^{2+}$ indicators with greatly improved fluorescence properties. J. Biol. Chem. 260:3440-3450.

24. Cantor, H., and E. A. Boyse. 1975. Functional subclasses of T lymphocytes bearing different Ly antigens. I. The generation of functionally distinct $T$-cell subclasses in a differentiative process independent of antigen. J. Exp. Med. 141:1376-1389.

25. Reinherz, E. L., and S. F. Schlossman. 1980. The differentiation function of human T cells. Cell. 19:821-827.

26. Swain, S. L. 1981. Significance of lyt phenotypes: lyt2 antibodies block activities of $\mathrm{T}$ cells that recognize class I major histocompatibility complex antigens regardless of their function. Proc. Natl. Acad. Sci. USA. 78:7101-7105.

27. Landegren, U., U. Ramstedt, I. Axberg, M. Ullberg, M. Jondal, and $H$. Wigzell. 1982. Selective inhibition of human $T$ cell cytotoxicity at levels of target recognition or initiation of lysis by monoclonal OKT3 and Leu 2a antibodies. J. Exp. Med. 155:1579-1584.

28. Ledbetter, J. A., R. L. Evans, M. Lipinski, C. Cunningham- 
Rundles, R. A. Good, and L. A. Herzenberg. 1981. Evolutionary conservation of surface molecules that distinguish $T$ lymphocyte helper/ inducer and cytotoxic/suppressor subpopulations in mouse and man. J. Exp. Med. 153:310-323.

29. Stanton, T., T. L. Stevens, J. A. Ledbetter, and D. Wofsy. 1986. Anti-Ly- 1 antibody induces interleukin 2 release from T cells. J. Immunol. 136:1734-1737.

30. June, C. H., P. S. Rabinovitch, and J. A. Ledbetter. 1987. CD5 antibodies increase intracellular ionized calcium concentration in $\mathrm{T}$ cells. J. Immunol. 138:2782-2792.

31. Parham, P., C. J. Barnstable, and W. F. Bodmer. 1979. Use of a monoclonal antibody (W6/32) in structural studies of HLA-A, B, C antigens. J. Immunol. 123:342-349.

32. Tsoukas, C. D., D. A. Carson, S. Fong, and J. H. Vaughan. 1982. Molecular interaction in human T cell-mediated cytotoxicity to EBV. II. Monoclonal antibody OKT3 inhibits a post-killer-target recognition/adhesion stem. J. Immunol. 129:1421-1425.

33. Krensky, A. M., E. Robbins, T. A. Springer, and S. J. Burakoff. 1984. LFA-1, LFA-2, and LFA-3 antigens are involved in CTL-target conjugation. J. Immunol. 132:2180-2183.

34. Ledbetter, J. A., and L. A. Herzenberg. 1979. Xenogeneic monoclonal antibodies to mouse-lymphoid differentiation antigens. Immunol. Rev. 47:63-89.

35. Ledbetter, J. A., R. V. Rouse, H. S. Micklem, and L. A. Herzenberg. 1980. T cell subsets defined by expression of Lyt-1, 2, 3 and Thy-1 antigens. Two-parameter immunofluorescence and cytotoxicity analysis with monoclonal antibodies modifies current views. J. Exp. Med. 152:280-295.

36. Hollander, N., E. Pillemer, and I. L. Weissman. 1980. Blocking effect of Lyt-2 antibodies on T cell functions. J. Exp. Med. 152:674687.

37. Hollander, N., E. Pillemer, and I. L. Weissman. 1981. Effect of Lyt antibodies on T-cell functions: augmentation by anti-Lyt-1 as opposed to inhibition by anti-Lyt-2. Proc. Natl. Acad. Sci. USA. 78:1148-1152.

38. Loden, M. R., R. D. Stout, and L. A. Herzenberg. 1979. Lymphoid cell analysis and sorting. In Flow Cytometry and Sorting. M. R. Melamed, P. F. Mullaney, and M. L. Mendelsohn, editors. John Wiley \& Sons, New York. 505-528.

39. June, C. H., J. A. Ledbetter, P. S. Rabinovitch, P. J. Martin, P. G. Beatty, and J. A. Hansen. 1986. Distinct patterns of transmembrane calcium flux and intracellular calcium mobilization after differentiation cluster antigen 2 (E rosette receptor) or 3 (T3) stimulation of human lymphocytes. J. Clin. Invest. 77:1224-1232.

40. Rabinowitch, P. S., C. H. June, A. Grossmann, and J. A. Ledbetter. 1986. Heterogeneity among $T$ cells in intracellular free calcium responses after mitogen stimulation with PHA or anti-CD3. Simultaneous use of Indo-1 and immunofluorescence with flow cytometry. J. Immunol. 137:952-961.

41. Ledbetter, J. A., C. H. June, L. S. Grosmaire, and P. S. Rabinovitch. 1987. Crosslinking of surface antigens causes mobilization of intracellular ionized calcium in T lymphocytes. Proc. Natl. Acad. Sci. USA. 84:1384-1388.
42. Smith, B. R., J. M. Rappeport, S. J. Burakoff, and K. A. Ault. 1987. Clinical correlates of unusual circulating lymphocytes appearing post marrow transplantation. In Recent Advances in Bone Marrow Transplantation. R. P. Gale, and R. Champlin, editors. Alan R. Liss, Inc., New York. 53:659-663.

43. Aisenberg, A. C., B. M. Wilkes, N. L. Harris, K. A. Ault, and R. W. Carey. 1981. Chronic T-cell lymphocytosis with neutropenia: report of a case studied with monoclonal antibody. Blood. 58:818-822.

44. Reynolds, C. W., and K. A. Foon. 1984. T $\gamma$-lymphopholiferative disease and related disorders in humans and experimental animals: a review of the clinical, cellular, and functional characteristics. Blood. 64:1146-1158.

45. Dillman, R. O., D. L. Shawler, J. B. Dillman, and I. Royston. 1984. Therapy of chronic lymphocytic leukemia and cutaneous T-cell lymphoma with T101 monoclonal antibody. J. Clin. Oncol. 2:881891.

46. Foon, K. A., R. W. Schroff, P. A. Bunn, D. Mayer, P. G. Abrams, M. Fer, J. Ochs, G. C. Bottino, S. A. Sherwin, D. J. Carlo, R. B. Herberman, and R. K. Oldham. 1984. Effects of monoclonal antibody therapy in patients with chronic lymphocyte leukemia. Blood. 64:1085-1093.

47. Smith, B. R., J. M. Rappeport, J. M. Lipton, M. Kligerman, M. Crimmins, N. Warner, R. A. Miller, and S. J. Burakoff. 1984. Marrow $T$ cell depletion with anti-Leu-1 monoclonal antibody (MAb) and complement in matched and mismatched bone marrow transplantation (BMT). Blood. 64(Suppl. 1):221.

48. Gorin, N. C., L. Douay, J. P. Laporte, M. Lopez, R. Zittoun, B. Rio, R. David, J. Stachowiak, J. Jansen, P. Casellas, P. Poncelet, M. C Liance, G. A. Voisin, C. Salmon, G. Le Blanc, J. Deloux, A. Najman, and G. Duhamel. 1985. Autologous bone marrow transplantation with marrow decontaminated by immunotoxin T101 in the treatment of leukemia and lymphoma: first clinical observations. Cancer Treat. Rep. 69:953-959.

49. Strong, R. C., F. Uckun, R. J. Youle, J. H. Kersey, and D. A. Vallera. 1985. Use of multiple $T$ cell-directed intact ricin immunotoxins for autologous bone marrow transplantation. Blood. 66:627635.

50. Martin, P. J., J. A. Hansen, C. D. Buckner, J. E. Sanders, H. J. Deeg, P. Sterwart, F. R. Appelbaum, R. Clift, A. Fefer, R. P. Witherspoon, M. S. Kennedy, K. M. Sullivan, N. Flournoy, R. Storb, and E. D. Thomas. 1985. Effects of in vitro depletion of T cells in HLAidentical allogeneic marrow grafts. Blood. 66:664-672.

51. Racadot, E. Herve, F. Beaujean, J.-P. Vernant, M. Flesch, E. Plouvier, G. Andreu, B. Rio, N. Philippe, G. Souillet, J. Pico, P. Bordigoni, N. Ifrah, M.-L. Paitre, P. Lutz, J. Morizet, and A. Bernard. 1987. Prevention of graft-versus-host disease in HLA-matched bone marrow transplantation for malignant diseases: a multicentric study of 62 patients using 3-Pan-T monoclonal antibodies and rabbit complement. J. Clin. Oncol. 5:426-435.

52. Kernan, N. A., N. H. Collins, L. Juliano, T. Cartagena, B. Dupont, and R. J. O'Reilly. 1986. Clonable T lymphocytes in T celldepleted bone marrow transplants correlate with development of graft-v-host disease. Blood. 68:770-773. 